\title{
Why some Jehovah's Witnesses accept blood and conscientiously reject official Watchtower Society blood policy
}

\author{
Lee Elder The Associated fehovah's Witnesses for Reform on Blood
}

\begin{abstract}
In their responses to Dr Osamu Muramoto (hereafter Muramoto) Watchtower Society (hereafter WTS) spokesmen David Malyon and Donald Ridley (hereafter Malyon and Ridley), ${ }^{1-3}$ deny many of the criticisms levelled against the WTS by Muramoto. ${ }^{46}$ In this paper I argue as a fehovah's Witness (hereafter $\mathcal{F} W$ ) and on behalf of the members of AFWRB that there is no biblical basis for the WTS's partial ban on blood and that this dissenting theological view should be made clear to all $\mathcal{F W}$ patients who reject blood on religious grounds. Such patients should be guaranteed confidentiality should they accept whole blood or components that are banned by the WTS. I argue against Malyon's and Ridley's claim that WTS policy allows freedom of conscience to individual $\mathcal{F W s}$ and that it is non-coercive and non-punitive in dealing with conscientious dissent and I challenge the notion that there is monolithic support of the WTS blood policy among those who identify themselves as $\mathcal{F W s}$ and carry the WTS "advance directive".

(Fournal of Medical Ethics 2000;26:375-380)
\end{abstract}

Keywords: Blood transfusion; Jehovah's Witnesses; Watchtower; autonomy

\section{Introduction}

In view of the response from WTS representatives Malyon and Ridley to Muramoto's articles regarding the medical community's dilemma in treating JW patients with blood, I thought it appropriate to present another viewpoint from within the ranks of JWs themselves. A significant number of JWs have concluded that they cannot support the WTS's blood policy. By questioning irrational aspects of this policy physicians in different countries have helped individual JWs, JW elders and hospital liaison committee members (hereafter HLC), to understand the inconsistencies in the WTS's blood doctrine.

I am a third generation JW, have for most of my life been a loyal adherent to WTS doctrine, and was a congregation elder for ten years. My maternal grandmother had her life cut short by her unswerving loyalty to the WTS's mandate forbidding JWs from accepting a blood transfusion. Might she have been persuaded differently if her physician had discussed with her the facts as suggested by $\mathrm{Mu}$ ramoto? Perhaps. She was not offered a choice.
As loyal JWs we have little choice but to accept unquestioningly WTS dictates. To question the organisation and its policies is tantamount to questioning the authority of Almighty God, and is nearly certain to result in being called before a tribunal of elders in the congregation on charges of "apostasy". Unless repentance is expressed to a degree that satisfies organisational representatives, one is subject to the harshest sanction of the WTS, that of expulsion (being "disfellowshiped") from the organisation, with the associated shunning mandate imposed. According to a 1994 statement, each year the WTS disfellowships some 40,000 members, or approximately one per cent of its membership. This means isolation from normal association or fellowship with family and lifelong friends who are members - not even being greeted by them if they pass you on the street. ${ }^{7}$ Unless repentance and humility are demonstrated by disfellowshiped members for months or years, with subsequent "reinstatement", the penalties permanently remain in force.

\section{Malyon, Ridley and the WTS evade the critical issues}

With great interest many of us read Malyons and Ridley's responses to Muramoto, for it is inconceivable that these articles were published without approval from the highest echelons of authority in the WTS. Previously, members of AJWRB sought clarification from the WTS on the issues $\mathrm{Mu}-$ ramoto raised, with no replies besides verbal advisement not to pursue the matter. If we expected answers or rational explanations for the glaring contradictions in the WTS's blood doctrine, we were in for another disappointment.

Perhaps it should have been no surprise that Malyon and Ridley upheld the WTS's position and skirted the controversial issues. Still we feel compelled to ask: "Where are the answers to the serious questions Muramoto raised?”

Foremost among these would be:

The Bible verses against "taking in blood" refer to eating or drinking it. What scripture extends this to blood transfusion?

If the scriptures ban blood transfusion why does the WTS allow transfusion/injection of all blood fractions while banning transfusion of whole blood? 
Why does the WTS permit JWs to accept all the separate components of plasma, yet forbid plasma itself?

Why are components such as platelets $(0.17 \%$ of blood volume) and white cells ( $1 \%$ of blood volume) forbidden whereas a larger component like albumin $(2.2 \%)$ is allowed?

What sort of ethics allows JWs to accept numerous WTS-permitted blood products and benefit from the donated blood of non-JWs, yet not allow them to contribute to the blood supply?

Since permitted haemophiliac treatments require collection and storage of massive quantities of blood (up to 2,500 units for a single treatment), why does the WTS forbid JWs from storing their own blood? Why the double standard?

Why did the WTS's application to the European Commission on Human Rights (hereafter ECHR) state that there are "no controls or sanctions" against a JW who accepts blood (or non-approved blood components) when every JW knows otherwise?"

\section{Malyon defends policy changes}

The Associated Jehovah's Witnesses for Reform on Blood has documented many modifications to the WTS's blood policy. ${ }^{10}$ Life and death decisions were made based on these policies, and compliance was generally mandatory. Malyon defends these changes by asking: "Since when has changing one's mind been a vice?" His misleading implication is that JWs as a group changed their mind on the use of blood, blood components, organ transplants and vaccines. In truth, only the WTS governing body is allowed such intellectual freedom.

Rank and file JWs must submit to current WTS policies or face a "judicial committee" and be disfellowshiped - a procedure that Malyon defends by comparing it to a doctor having his licence suspended by the General Medical Council (GMC). However, would the GMC attempt to prevent the doctor's friends and family from speaking to him? Would they suspend the licences of other physicians because they continued to speak with a doctor whose licence was suspended? Is this not a false analogy?

Furthermore, the WTS judicial process is not an "examination by peers" as Malyon claims. There is no complete transcript of the proceeding upon which an appeal could be based, no right to representation, no rules of evidence, etc. It is a "Star Chamber" affair with inadequate checks and balances. Malyon attempts to defend vacillating WTS medical policy by comparing it with that of other organisations, such as the British Medical Association (BMA), that may have changed their views on issues such as vaccination. However, unlike the WTS, the BMA bases its decisions on sound scientific discovery and does not enforce compliance with its medical advice through extreme disciplinary measures that assume exclusive divine authority from Almighty God.

I doubt that Malyon or Ridley could have anticipated the significant revisions the WTS made to its blood policy as outlined in a "Questions From Readers" article in the June 15, 2000 issue of The Watchtower. ${ }^{8}$ Therein we find what appear to be subtle changes but closer examination reveals meaningful reforms.

The WTS appears to have once again changed its policy concerning the blood fractions it will permit a JW to accept. The WTS now stipulates that while the "primary components" of blood-namely red cells, white cells, platelets and plasma-are forbidden and fractions of $\boldsymbol{a l l}$ "primary components" are now permitted. Though such terms are meaningless to a Christian-the Bible says nothing about primary or secondary components - the policy seems to reflect the fact that blood banks commonly separate blood in this manner for commercial reasons.

Perhaps most interesting is that the article states that "when it comes to fractions of any of the primary components, each Christian, after careful and prayerful meditation, must conscientiously decide for himself" :

The statement is subtle and some JWs will initially miss its importance. Nevertheless, it signals an important shift in policy-JWs may now conscientiously accept $\boldsymbol{a n y}$ blood product that is a "fraction extracted from the primary components". Previously, JWs were permitted to accept fractions of blood plasma only. Does this subtle change create the potential for JWs to benefit from haemoglobinbased blood substitutes that are under development? It appears to do just that since haemoglobin is obtained by fractionating red cells. These developments must be monitored closely since blood substitutes have the potential dramatically to reduce deaths among the JW population. I am pleased by this development although I am concerned about the level of confusion among JWs and the medical community since the WTS in typical fashion obfuscates its intentions so as not to provoke controversy among the membership.

\section{The chaos of the WTS blood policy}

In October, 1999 AJWRB hosted a booth at the American College of Emergency Physicians' conference in Las Vegas, Nevada, USA. There we had opportunity to take our message directly to physicians and to hear their thoughts and concerns. A recurring theme in these exchanges was the confusion among doctors as to which blood therapies JWs accept and the ethical dilemma doctors face when presented with an unconscious exsanguinating JW patient.

One physician related an experience involving an unconscious twenty-one-year-old JW man who needed a blood transfusion. He carried the WTS "advance directive", and the family insisted that no blood transfusions be given. At one point the man regained consciousness and stated he did not want to die. He requested the transfusion, which was given and the man's life was saved. What if, however, the patient had not temporarily regained consciousness? This man, like all JWs, meets in a small group called a "book study", where an elder is 
usually present to see that each member has completed his/her "advance directive" and had his/ her signature properly witnessed. Since a measure of coercion and duress may be present in conjunction with the signing of the "advance directive", and since some JWs will accept blood under certain circumstances, we have an ethical dilemma, especially for emergency physicians. These conditions, coupled with the fact that few physicians, and even JWs themselves, understand the complexities of the WTS blood policy, are a recipe for disaster. It is not uncommon for JWs to reject treatments or blood therapies the WTS permits simply because they are unaware they may now accept them. The WTS's blood policy remains in a state of disorder with no credible answers to the core issues raised by AJWRB. Furthermore, some JWs, including significant numbers of elders and HLC members, have concluded they can no longer conscientiously support WTS policy. Many are frustrated by the WTS's failure to provide meaningful answers and are deeply troubled over the death toll this policy has produced. Malyon paints a picture of monolithic support for the blood policy within the JW community. Nothing could be further from the truth.

\section{Risk/benefits of blood transfusions}

Malyon gives considerable attention to defending the efficacy of alternative non-blood therapy. Are HLC members such as Malyon qualified to assess the medical needs of individual JWs confronted with a decision between blood or non-blood therapies, or is this the role of the physician? It is noteworthy that a group of eight HLC members has issued a treatise advising caution with respect to the use of non-blood techniques since they have observed tragic results from such procedures within the JW community. ${ }^{11}$ As Doyle points out: "Although much has been made about a medical rethinking of the risk/benefit properties of blood transfusions as a result of HIV and AIDS, blood transfusions remain essential to life in a large number of clinica situations. Patients who refuse a blood transfusion deemed absolutely medically necessary by a physician put themselves at risk of dying from severe anaemia. For example Carson et al studied 125 surgical patients who were Jehovah's Witnesses and thus refused blood transfusion. It was found that over $60 \%$ of patients whose preoperative hemoglobin fell below $6 \mathrm{~g} / \mathrm{dl}$ died following the surgery."

\section{Blood transfusions and JW children}

Malyon presents a distorted picture of the WTS's position on JW children with respect to the blood issue. He states that a "child cannot be one of Jehovah's Witnesses" since JWs practise "mentally competent" baptism. (Baptism is the formal rite for induction into JW membership.) In truth, the WTS allows very young children to be baptised as long as they can correctly answer certain questions. I was baptised at the age of nine. This is not uncommon, as the WTS has acknowledged. ${ }^{13}$ Baptised children of this tender age are expected to understand the complexities of the blood issue and to support the WTS blood policy if the occasion arises, even to remove the IV from their arm if necessary to prevent the transfusion. ${ }^{14}$ Failure to comply with WTS policy could result in disfellowshiping, the same as an adult.

Featured on the cover of the May 22, 1994 Awake! magazine (an official WTS publication) are the photos of 26 JW children, with the caption "Youths Who Put God First." Inside, the magazine proclaims: "In former times thousands of youths died for putting God first. They are still doing it, only today the drama is played out in hospitals and courtrooms, with blood transfusions the issue". ${ }^{15}$ The government of Bulgaria was sufficiently concerned by this situation to stipulate in its agreement with the WTS that baptised JW minors may not be issued the WTS "advance directive", which forbids the use of blood and blood components disallowed by the WTS in the event of an emergency. ${ }^{16}$

How intent is the WTS on preventing JW children from receiving a blood transfusion? Notice these comments directed to JW parents in the September 1992 issue of Our Kingdom Ministry (a publication not distributed to the public), on pages 3-5: “... have you taken every reasonable step to protect your young children from a blood transfusion?... it should be made clear to all concerned that you, as parents, feel an obligation to continue to do all that you can to avoid a transfusion. This is your God-given responsibility. ... If a court order is issued despite your best efforts, continue to implore the physician not to transfuse. ... So, even after a court order has been issued, never give up, regardless!"

To comply, JW parents have been known to defy doctors and take desperately ill children out of a hospital to avoid a court-ordered blood transfusion. ${ }^{17}$ Do JWs simply conclude on their own that this is something they should do? Note the following comments from The Watchtower to Witness parents: "If a Christian did put forth very strenuous efforts to avoid a violation of God's law on blood, authorities might consider him a lawbreaker or make him liable to prosecution. If punishment did result, the Christian could view it as suffering for the sake of righteousness." 18

Nevertheless, Malyon's comments may indicate that the WTS position on transfusing children is beginning to soften. However, it is my belief that as with concessions made in Bulgaria, the WTS is simply compromising in countries where the government is assertive about protecting the lives of minor children. I hope that other governments will take note of what transpired in Bulgaria and prevent the WTS from issuing "advance directives" to JW minors.

\section{Malyon, Ridley and the WTS must be viewed with skepticism}

As noted by Muramoto, JWs living in the country of Bulgaria appear to be an exception to the WTS blood policy. In that country, according to the WTS application to the ECHR and later agreement with 
Bulgaria, JWs are free to choose blood therapies "without any control or sanctions" from the WTS. ${ }^{19}$ Unfortunately, most JWs are unaware the WTS entered into such an agreement, or they are led to believe it is a misinterpretation propagandised by "apostates" (former members), or perhaps an error made by the ECHR, since the WTS proclaims no change in the blood policy. The fact that JWs so willingly believe this is further testimony to the control the WTS exerts over most members, which makes them unreceptive to information that would give them a better understanding of the issues.

The WTS's official application to the ECHR blatantly misrepresents its blood policy by stating that there are no controls or sanctions for a JW who accepts blood. The document can be viewed at the AJWRB internet web site. ${ }^{9}$ We also possess a press release issued by the WTS public affairs office wherein the WTS claims that no policy change has occurred in Bulgaria. ${ }^{20}$ We must then ask which is true, their application to the ECHR and subsequent agreement with Bulgaria or their press release? Malyon, Ridley and the WTS attempt to sidestep this issue by stating that they don't "arbitrarily apply sanctions", that they do not have an "automatic disfellowshiping policy", that they want to offer "pastoral care" and that in these senses "no controls or sanctions" exist. Such tortured logic is analogous to stating there is no "sanction" for capital murder, since neither the verdict nor the sentence is arbitrarily applied or automatic!

\section{Freedom within the Watchtower Society}

Ironically, WTS representatives, if asked, will maintain that JWs are "free to choose" which blood therapies they may accept. This is a semantic dodge since JWs are allowed to accept, without disciplinary action, only certain blood components presently permitted by the organisation. What these spokesmen mean is that JWs are "free to choose" if they are willing to accept the consequences, including expulsion. By that logic, people are free to disobey laws of the land if they are willing to pay the penalties for so doing. I once served with an elder who told me he felt he would have no choice but to disfellowship someone who took a blood transfusion. Although that man's views do not represent that of all JW elders, I believe the view is common.

On June 14, 1998, I granted a radio interview to Roger Bolton of the BBC, along with Paul Gillies, an official spokesman for the WTS in London. ${ }^{2}$ During the programme Mr Gillies was asked the following question by interviewer Roger Bolton: "Is there any scope for democratic debate among Jehovah's Witnesses? I mean, you could argue, you know, you've changed your mind on transplants, couldn't you change your mind on blood transfusions? Shouldn't there be an open debate among members?"

Paul Gillie's response: "Well, we do encourage open discussion. In fact, we encourage every family head to discuss with his family all the various medical procedures and implications of blood with his family so that, if a medical situation arises, he's quite clear in his own mind what various choices he has and what he can do. In our meetings, too, we have open discussions."

This statement is, again, another example of sidestepping the issue by the use of misleading words. While it implies that there is a measure of latitude for families and congregations to discuss openly the full range of blood therapies and make personal decisions about which ones they might accept, this obviously is not true. If this is true, then why does the WTS disfellowship members who speak openly and sometimes privately against the current policy? In 1999, a JW man in the USA, Wayne Rogers, was reported by his wife to congregation elders simply because he sent an e-mail to AJWRB expressing support of our efforts to promote reform of this WTS doctrine. The man was promptly disfellowshiped despite his plea for mercy and desire to remain a JW. Shortly thereafter the elders apparently told the man's wife that she was entitled to leave him since remaining with an apostate posed "absolute spiritual endangerment". This is the sad reality of WTS "pastoral care", and is not an isolated incident. So much for Mr Ridley's assurances of "normal family affections and dealings". Recently a JW in the UK, Ray Hemming, was disfellowshiped for simply questioning the WTS blood policy and Rado Vleugel, a JW regular pioneer (full-time minister) in the Netherlands, was disfellowshiped after speaking with journalists about the WTS blood policy. One JW woman who is an AJWRB member stated it well: "What, then, is free will or freedom of choice? If a robber holds a gun to my head and tells me to give him my money, do I have free will when making my decision? I don't really want to give him my money, but also I don't want to die. Not much of a free choice, is it? ... the WTS holds the same power over JWs.... In the case of accepting certain blood products, the choice is either to die or be disfellowshiped for following one's conscience. Nothing like having a 'WTS gun' held to my head. My money is not being stolen, my peace of mind is."

There is little room for freedom or patient autonomy within the current WTS system, despite the claims of Malyon, Ridley, and the WTS.

\section{'High-control' authoritarian groups}

Malyon not only failed to address the core issues Muramoto raised and to come to terms with the cognitive dissonance brought on by serious evaluation of WTS teachings on blood, but dismissed the views of current and former JWs who disagree with the WTS as coming from "disaffected ones". In criticising JW dissidents like myself for presenting our case anonymously, he disregards the obvious fact that the WTS's enforced legalism allows no viable alternative, as already discussed at length. So Malyon has provided an excellent demonstration of how a rational individual comes to yield to the authority of a high-control religious group. Ridley dismisses the existence of mind control among JWs and cites a report which "determined that theories 
of coercive manipulation or 'mind control' as applied to religious movements lacked any scientific foundation and should not be presented as scientific". Muramoto will address Ridley's comments in an article to be published in this journal. My observation is that the existence of group coercion among JWs is real and not in serious dispute since the WTS aggressively endeavours to control the emotions, behaviour and thoughts of its members, as well as the flow of information. In my own case the pressure to conform led me to continue carrying a WTS advance directive in my wallet for nearly three years after I no longer accepted the policy.

\section{Why AJWRB members believe the WTS blood policy is wrong}

While we acknowledge that the Bible does speak against the misuse of blood, it is important to note that this is always in the context of using it as food, as The Watchtower has acknowledged: "Each time the prohibition of blood is mentioned in the Scriptures it is in connection with taking it as food, and so it is as a nutrient that we are concerned with its being forbidden". ${ }^{22}$

The primary issue is whether or not a blood transfusion is the equivalent of eating blood. Clearly, it is not. A blood transfusion is not a meal but rather a tissue or organ transplant. There is no nutritional benefit as would be the case if a person were to eat blood and digest it. The WTS has tried to overcome these facts by likening a blood transfusion to intravenous feedings.

However, because compounds like dextrose are used by the body as food without digestion this analogy is wrong. Transfused blood cannot be used by the body as food any more than a transplanted heart or kidney can.

The following analogy may prove helpful. Consider two patients who are unable to eat, and are admitted to a hospital. One is given a blood transfusion and the other intravenous feedings. Which one is receiving nourishment and will live? Clearly, doctors do not prescribe blood transfusions to treat malnutrition, but rather to replace something the patient's body has lost, usually the red cells needed to transport oxygen. Since it cannot be established that blood transfusion is a feeding on blood or the equivalent of eating blood, the critical link for biblical support of the WTS blood policy does not exist.

\section{Reasoning with JW patients who are unfamiliar with AJWRB}

Before discussing the lack of biblical foundation for the WTS blood policy, we believe it is helpful first to first encourage the JW patient actually to think about the contradictions of the WTS blood policy. We propose using the following questions and statements:

"Could you, as a JW, please explain to me which blood therapies you can accept, which you cannot, and why the difference?" "I am especially interested in knowing where the Bible explains which parts of the blood you may or may not accept." "Please do not give me a publication that I'm too busy to read, or ask me to speak with an elder from your congregation. It's important that I understand what you are thinking and why you are prepared to die over this issue if non-blood alternatives are exhausted."

Please note that some JWs are unaware that the WTS permits members to accept all blood products produced from fractionating red cells, white cells, platelets and plasma. This would include, but is not limited to, the following: albumin, all clotting factors, all immunoglobulins, fibrinogen, EPO, interferons, interleukins, and other cellular fractions. ${ }^{23}$

You are invited to visit the physician's section of AJWRB's web site where you will find extensive resources to assist you. The address is: http:// www.ajwrb.org. Physicians, medical ethicists, hospital chaplains and other interested persons may obtain up-to-date information and helpful brochures from the web site or by writing directly to AJWRB.

\section{Conclusion}

I sincerely hope that physicians will follow $\mathrm{Mu}$ ramoto's suggestions to pursue rational noninterventional paternalism. As Muramoto revealed, they will discover that most JWs are not adequately informed to make an autonomous decision about blood treatment. Yet, sadly, they are prepared to sacrifice their own lives or the life of a child to support an irrational policy that is frequently revised and may one day be abandoned altogether, as have previous WTS bans on vaccines, organ transplants and numerous blood components. Until such time, the best hope for JWs is that concerned physicians will engage them in the kinds of discussion suggested by Muramoto.

In this manner, the loss of life can be, and already has been reduced. It is my belief that heightened public scrutiny may compel the WTS to reform its blood doctrine so that JWs will have the freedom to make a conscientious choice without fear of sanctions that would separate them from their friends and loved ones.

\section{About the author}

The author's interest in the WTS blood doctrine was heightened following a series of exchanges with a physician over the internet in 1995. He spent the balance of 1996 researching the history of the policy before concluding a tragic mistake had been made. After failing to open a dialogue with Daniel Sydlik, a WTS governing body member, the author opened the internet web site "New Light on Blood". It quickly became apparent that many $\mathcal{F W}$ elders and HLC members had reached similar conclusions, but had no forum in which to safely to discuss them. The author is the founder of AFWRB and maintains his status as a $\mathcal{F W}$, which requires anonymity for his internet and reform activities with 
AFWRB. Fear of draconian punishment forces him to write under a pseudonym, but the editor is assured of his bona fides. His diligence for seeking reform of the WTS blood doctrine is motivated by his concern for fellow FWs. Lee Elder, (The Liberal Elder), is Director of The Associated Fehovah's Witnesses for Reform on Blood $(A \mathcal{F W R B})$.

\section{References and notes}

1 Malyon D. Transfusion-free treatment of Jehovah's Witnesses: respecting the autonomous patient's rights. Fournal of Medical Ethics 1998;24:302-7.

2 Malyon D. Transfusion-free treatment of Jehovah's Witnesses: respecting the autonomous patient's motives. Fournal of Medical Ethics 1998;24:376-81.

3 Ridley D. Jehovah's Witnesses' refusal of blood: obedience to scripture and religious conscience. Fournal of Medical Ethics 1999:25:469-72

4 Muramoto O. Bioethics of the refusal of blood by Jehovah's Witnesses: part 1. Should bioethical deliberation consider dissidents' views? Fournal of Medical Ethics 1998;24:223-30.

5 Muramoto O. Bioethics of the refusal of blood by Jehovah's Witnesses: part 2. A novel approach based on rational non-interventional paternalism. Fournal of Medical Ethics 1998; 4:295-301

6 Muramoto O. Bioethics of the refusal of blood by Jehovah' Witnesses: part 3. A proposal for a don't-ask-don't-tell policy. fournal of Medical Ethics 1998;25:463-8.

7 Anonymous. Are you resisting the spirit of the world? The Watchtower 1994 Apr 1:16.

8 Anonymous. Questions from readers. The Watchtower 2000 Jun 15: 29-31

9 Anonymous. New light on blood. Watchtower commits perjury? AJWRB, 1998. URL: http://www.ajwrb.org/basics/
perjury.shtml

10 Anonymous. New light on blood. The historical perspective. AJWRB, 1997. URL: http://www.ajwrb.org/history/index.shtml
11 Anonymous. New light on blood. The HLC perspective. AJWRB, 1997. URL: http://www.ajwrb.org/basics/hlc.shtml

12 Doyle J. Risks of avoiding "necessary" blood transfusions. AJWRB,1998. URL: http://www.ajwrb.org/physicians/doylerisksavoiding.html

13 Anonymous. Trust in Jehovah leads to dedication and baptism. The Watchtower 1988 Mar 15: 14.

14 Anonymous. Youths who have "power beyond what is normal". Awake! 1994 May 22: 13.

15 Anonymous. Table of contents. Awake! 1994 May 22: 2.

16 Report of the European Commission on Human Rights. Application no 28626/95. New light on blood. The Bulgarian Files. AJWRB, 1998. URL http://www.ajwrb.org/bulgaria/ index.shtml

17 Anonymous. New light on blood. Stories that break hearts. AJWRB, 1997. URL: http://www.ajwrb.org/experiences/ stories.shtml\#blizzard

18 Anonymous. Questions From Readers. The Watchtower 1991 Sept 15: 31 .

19 The original document is available from: URL: http:/ 194.250.50.201/eng/E276INFO.148.html. Communique issued by the Secretary to the European Commission of Human Rights. Information note no 148 on the 276 th session of the European Commission of Human Rights. (Strasbourg, Monday 2 Mar-Fri 13 March 1998). The full text of the "friendly settlement" in French is available from URL:http:// 194.250.50.201/eng/28626.28.html.

20 Anonymous. WTS-Public Affairs Office. See: Watchtower blood policy in Bulgaria - a crime, an outrage, and a delusion! AJWRB, 1998. URL: http://www.ajwrb.org/basics/abandon.shtml

21 Transcript of interview with the Liberal Elder and Paul Gillies, spokesman for WTS, by Roger Bolton on Sunday, BBC Radio 4, on June 14, 1998. AJWRB, 1998. The document is available from: URL: http://www.ajwrb.org/newsmedia/bbs.shtml

22 Anonymous. Questions from readers. The Watchtower 1958 Sept 15: 575

23 Muramoto O. Recent developments in medical care of Jehovah's Witnesses. Western fournal of Medicine 1999;170:297301. 